\title{
Birth of the Canadian Digestive Health Foundation
}

\author{
Ivan T Beck MD PhD FRCPC FACP MACG
}

\author{
IT Beck. Birth of the Canadian Digestive Health Foundation. \\ Can J Gastroenterol 2004;18(1):29-37.
}

The Canadian Digestive Disease Foundation, renamed the Canadian Digestive Health Foundation - Fondation canadienne pour la promotion de la santé digestive - in December 2001, is the culmination of ongoing efforts by the Canadian Association of Gastroenterology to establish an independent charitable organization. In February 2001, it was officially endorsed as the Foundation for the Canadian Association of Gastroenterology.

The initial efforts to establish this Foundation, led by Dr Richard McKenna in 1963, were unsuccessful. In 1991, Glaxo Canada (now GlaxoSmithKline) became a founding donor, and with the four founding physicians - Drs Ivan T Beck, Richard H Hunt, Suzanne E Lemire and Alan BR Thomson - the expenses to establish the Foundation were met. A charitable number was obtained in 1995 (0997427-11). The second founding donor was Janssen Canada (now Janssen-Ortho), and public education support came from Astra Canada (now AstraZeneca Canada). The Foundation initially relied on corporate donors, but now approaches physicians, patients and the general public.

The objectives of the Foundation are to advance the science of gastroenterology and to provide knowledge of digestive diseases and nutrition to the general public, to enhance the quality of life of persons who are afflicted with these disorders.

The major achievements of the Foundation are the provision of oneyear operating grants to new investigators, which have allowed them to accumulate early data and subsequently obtain support from other major granting organizations. It also provides Fellowships and studentship support grants, in conjunction with the Canadian Institutes of Health Research and the pharmaceutical industry. The education committee found that there was little research support in this field, considering the large economic burden of digestive disease and the amount of outstanding work done by Canadian researchers. A bilingual Web site, a webbased specialist's discussion program and bilingual pamphlets facilitate public awareness and allow patients to voice concerns.

Key Words: Charitable organization; Education; Ethics; Gastroenterology; History; Research

\section{INITIAL HISTORY AND EARLY DEVELOPMENTS}

Since the Canadian Association of Gastroenterology (CAG) was established in 1962, the direct economic burden of digestive disorders has exceeded that of diseases of the cardiac, respiratory and central nervous systems (1-3). Nevertheless, there

\section{La naissance de la Fondation canadienne pour la promotion de la santé digestive}

La Fondation canadienne pour l'étude des maladies digestives (FCÉMD), devenue en 2001 la Fondation canadienne pour la promotion de la santé digestive (FCPSD), représente la culmination d'efforts continus de l'Association canadienne de gastroentérologie (ACG) visant à créer un organisme de bienfaisance indépendant. En février 2001, l'organisme est officiellement devenu la fondation de l'ACG.

Sous la direction du docteur Richard McKenna en 1963, les premiers efforts en vue d'établir cette Fondation sont restés lettres mortes. En 1991, Glaxo Canada (devenue GlaxoSmithKline) est devenue donateur fondateur et, avec les quatre médecins fondateurs, les docteurs Ivan T Beck, Richard H Hunt, Suzanne E Lemire et Alan BR Thomson, les fonds nécessaires pour établir la Fondation ont été recueillis. Un numéro d'organisme de bienfaisance a été obtenu en 1995 (0997427-11). Le deuxième donateur fondateur a été Janssen Canada (devenue JanssenOrtho), et le soutien en éducation publique a été assuré par Astra Canada (devenue Astra Zeneca Canada). Au début, la Fondation se fiait sur des sociétés commanditaires, mais elle sollicite maintenant les médecins, les patients et le grand public.

La Fondation vise à faire progresser la science de la gastroentérologie et à faire connaitre les maladies digestives et la nutrition au grand public afin d'améliorer la qualité de vie des personnes atteintes de troubles gastroentérologiques.

La Fondation réalise divers objectifs. Elle remet des subventions de fonctionnement d'un an à de nouveaux chercheurs, ce qui leur permet d'accumuler des données précoces et d'obtenir l'appui d'autres grands organismes subventionnaires. Elle offre également des bourses d'étude clinique et des subventions de soutien aux étudiants, conjointement avec les Instituts de recherche en santé du Canada (IRSC) et l'industrie pharmaceutique. Le comité d'éducation était d'avis que le soutien pour la recherche était minime dans ce domaine, compte tenu du fardeau économique important des maladies digestives et de la quantité de recherches remarquables menées par des chercheurs canadiens. Un site Web bilingue, un programme de discussion entre des spécialistes installé dans Internet et des dépliants bilingues favorisent la sensibilisation publique et permettent aux patients de formuler leurs préoccupations.

Gastrointestinal Disease Research Unit, Division of Gastroenterology, Department of Medicine and Physiology, Queen's University, Kingston, Ontario Correspondence and reprints: Dr Ivan T Beck, Gastrointestinal Disease Research Unit, Division of Gastroenterology, Department of Medicine and Physiology, Queen's University, 99 University Avenue, Kingston, Ontario K7L 3N6. Telephone 613-544-0225 ext 82-3058,

e-mail becki@hdh.kari.net

Received for publication May 14, 2003. Accepted October 30, 2003 
l'Etude des Maladies Digestives (FCEMD). In December 2001, the Foundation was renamed the Canadian Digestive Health Foundation (CDHF) - Fondation canadienne pour la promotion de la santé digestive (FCPSD).

Initial efforts to establish a charitable foundation were unsuccessful. In 1963, Dr Richard McKenna (the first Past President of the Association) (Figure 1a) chaired the CAG Fundraising Committee, which also included Drs Ivan Beck, Douglas Kinnear and Paul Letendre $(5,6)$. The lack of funds for legal expenses and organizational support, however, prevented further progress (7). Lack of money and manpower also thwarted subsequent work by committees chaired by Drs James Lind (1967) (Figure 1b), Douglas Kinnear (1969) (Figure 1c) and Roy Preshaw (1973) (Figure 1d) (8-11).

The situation changed in 1991 because of the generosity of Glaxo Canada. Mr Jacques Lapointe, (Figure 2a) chief executive officer of Glaxo Canada, and Mr Paul Lucas (who succeeded $\mathrm{Mr}$ Lapointe) were committed to advancing gastroenterology in Canada and supported a total of 35 Fellowship years between 1986 and 1992 (12). The introduction of proton pump inhibitors and generic ranitidine made it clear that Glaxo could not maintain indefinitely its considerable level of support. Therefore, the company set up a working group to explore ways that they could continue to develop gastrointestinal (GI) research and education. This committee included Dr Jean Francois Loumeau (Medical Director of Glaxo Canada), Mr Paul Meade (Product Manager for Zantac) and four physicians: Drs Ivan T Beck (Kingston) (Figure 2b), Suzanne E Lemire (Québec) (Figure 2c), Richard H Hunt (Hamilton) (Figure 2d) and Alan BR Thomson (Edmonton) (Figure 2e).

Donations by Glaxo Canada and the aforementioned physicians paid for the meetings and legal expenses that allowed the establishment of the CDDF. At an organizational meeting with 14 leading gastroenterologists on January 18, 1991 (Table 1), general approval was obtained to set up the Foundation (13). Legal affairs were handled by the Toronto firm of Gowling, Strathy and Henderson, and advice was also obtained from the health care organizational firm 'The Synapse Group'.

Because of major commitments as upcoming Presidents of the CAG, Drs Lemire and Hunt relieved themselves from further organizational efforts, and were replaced by Dr Micheline Ste-Marie (Halifax) (Figure 2f). Drs Beck, Thomson and SteMarie became interim directors of the Foundation. The application for a charitable number was prepared by Robert $\mathrm{N}$ Granger QC (a partner in Gowling, Strathy and Henderson) and submitted on April 23, 1993. A federal charitable number was obtained (0997247-11), with permission to start to function in January 1995.

\section{OBJECTIVES AND ORGANIZATION}

The organizing committee meeting in 1992 (14) established that the principal objective of the Foundation was to raise funds for the support of research, education and care for patients suffering from digestive disorders. The goals of the Foundation were to:

1. "advance the science and knowledge of diseases of the digestive organs;

2. assist research, training, prevention and treatment of conditions impairing the normal functions of the digestive organs, including their function in nutrition;
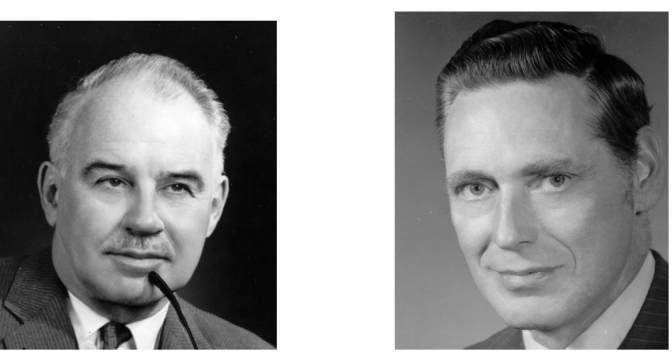

a.
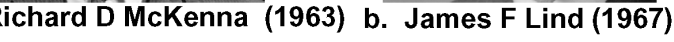

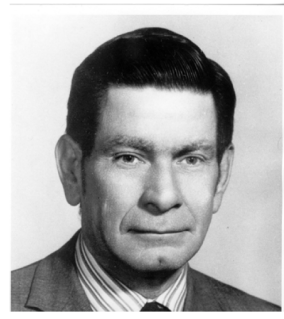

c. Douglas G Kinnear (1969)

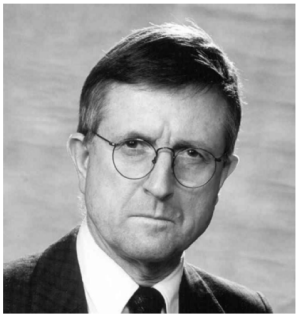

d. Roy Preshaw (1973)
Figure 1) Chairs of Canadian Association of Gastroenterology committees to establish a charitable organization (Photographs taken at the time when they worked on these committees). a Dr Richard D McKenna, 1963; b Dr James F Lind, 1967; c Dr Douglas G Kinnear, 1969; d Dr Roy Preshaw, 1973.

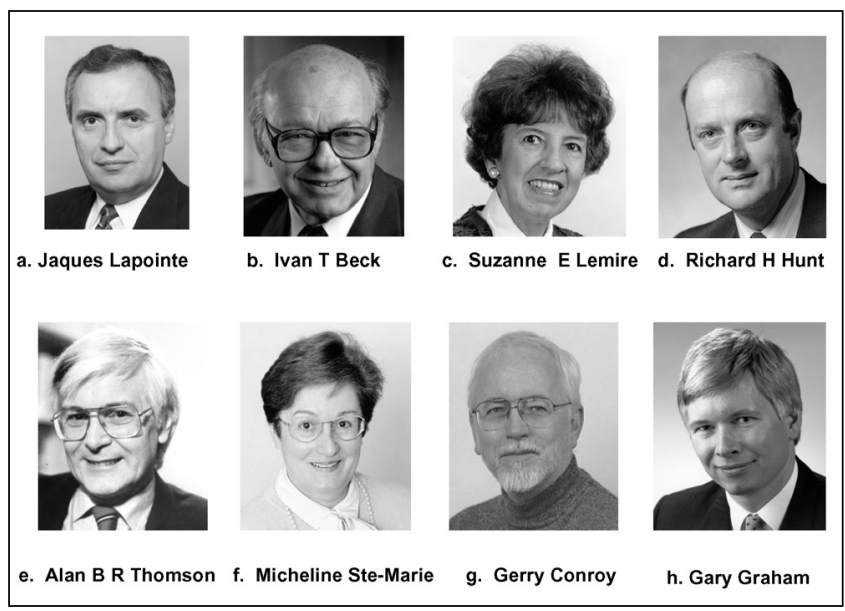

Figure 2) Early supporters of the Foundation. a Mr Jacques Lapointe, Chief Executive Officer, Glaxo Canada, and initiator of Glaxo's support of Canadian gastroenterology; b Dr Ivan T Beck, founding physician, 1991; c Dr Suzanne E Lemire, founding physician, 1991; d Dr Richard H Hunt, founding physician, 1991; e Dr Alan BR Thomson, founding physician, 1991; f Dr Micheline Ste-Marie, first President of the CDDF; $\mathrm{g} \mathrm{Mr}$ Gerry Conroy, nonphysician member of the first Board; h Mr Gary Graham, nonphysician member of the first Board

3. promote dissemination of knowledge of diseases of the digestive organs throughout the Canadian community; and

4. assist in the development of new methods to ensure better quality of life for people affected by these disorders." (14). 
TABLE 1

\begin{tabular}{|c|c|}
\hline \multicolumn{2}{|c|}{$\begin{array}{l}\text { Physicians involved in the organizational meeting on } \\
\text { January 18, } 1991 \text { to discuss the establishment of the } \\
\text { Canadian Digestive Disease Foundation (Minto Place } \\
\text { Hotel, Ottawa, Ontario) }\end{array}$} \\
\hline Dr I Beck (Kingston) & Dr R Hunt (Hamilton) ${ }^{\star}$ \\
\hline Dr M Boivin (Montréal) & Dr D Leddin (Halifax) \\
\hline Dr R Bourdages (Gaspé) & Dr S Lemire (Québec) \\
\hline Dr H Chaun (Vancouver) & Dr G Levy (Toronto) \\
\hline Dr L DaCosta (Kingston) & Dr E Shaffer (Calgary) \\
\hline Dr R Gillies (Ottawa) & Dr M Ste-Marie (Halifax) \\
\hline Dr H Haddad (Sherbrooke) & Dr A Thomson (Edmonton) \\
\hline
\end{tabular}

*Unable to attend

No other charitable organization in Canada shared the broad objectives of the Foundation. Discussions with the Crohn's and Colitis Foundation of Canada (CCFC) (then known as the Canadian Foundation for Ileitis and Colitis) and the Canadian Liver Foundation led to their acceptance of the CDDF (15). Relations with the CCFC and the CLF were formalized in September 1991 by Dr Shaffer (President of the CAG) and approved by the CAG board in February 1992 (16). The CDDF informed the CCFC of its progress by ongoing correspondence between Dr Ste-Marie and Dr TE Hannah (VicePresident of the CCFC) (17). In a letter dated April 27, 1995, Dr Hannah, in the name of the president of the CCFC, wrote to Dr Ste-Marie (Appendix A).

The CDDF was, therefore, established with the full approval of both the CAG and the CCFC.

The first Executive Committee of the CDDF (1994) consisted of Drs Micheline Ste-Marie (President), Alan Thomson (Secretary/Treasurer) and Ivan Beck (Chair of the Board) (18). Mr Gerry Conroy (Figure 2g) of the Synapse Group volunteered to advise the Foundation about fundraising and recruitment of lay members to the board, and Mr Gary Graham (Figure 2h), (of Gowling, Strathy and Henderson, and past Chair of the Canadian Man ufacturers' Association) volunteered legal services. Mr Conroy also served as Chair of the Public Relations Committee. The original members of the Education Committee were Drs Micheline Ste-Marie (Chair), Hugh Chaun (Vancouver), Alan Barkun (Montreal) and Ford Bursey (St John's). The members of the Research Committee were Drs Ivan Beck (Chair), Joseph Davison (Calgary), Gordon Forstner (Toronto), Gordon Greenberg (Toronto), Micheline Ste-Marie, Alan Thomson and Carl Goretsky (Montréal). With the early death of Dr Goretsky, Dr Andrée Weber (Montréal) and, later, Dr Stephen Vanner (Kingston) were asked to become members, and Dr Vanner eventually became Chair of the committee in 1998.

Dr Alan Thomson created a logo for the Foundation. With the support of Astra Canada through Mr Peter Dixon (Product Manager for gastrointestinal drugs for Astra Canada) (Figure 3a) a film aired nationally and brochures were prepared for public awareness (Figures 3b, c, d and e). Astra provided financial support for the business plan, formulated by Fleishman-Hillard Inc, Canada (19). The plan called for efforts to solicit corporate sponsorship - from financial institutions and nonpharmaceutical companies that might be affected by employee absenteeism due to digestive diseases - as well as individual donations from physicians and members of the general public (20). After a brief delay (21), the Board of the Foundation was

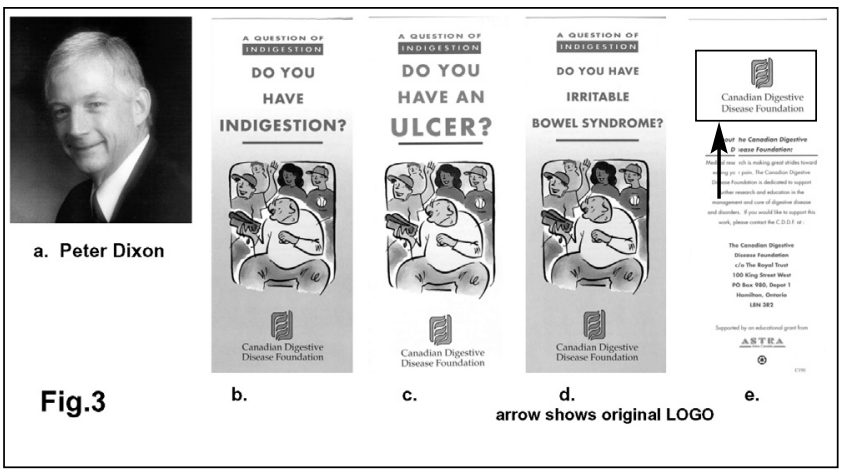

Figure 3) Initiator of and first CDDF brochures of 1995. a Peter Dixon, Product Manager for gastrointestinal drugs, Astra Canada; b Do you have indigestion?; c Do you have an ulcer?; d Do you have irritable bowel syndrome?; e Back page of all three pamphlets requesting donations (The logo of the Foundation of 1995 is in a square and indicated by arrow on $\mathrm{e}$

able to secure a charitable number (0997247-11) that became valid in January 1995 (22). At the same time, Janssen Canada donated \$150,000 and became the second Founding Donor.

The names of Founding Donors, Glaxo Canada and Janssen Canada, were listed on the Foundation letterhead (23). This status required donation of at least $\$ 150,000$, although other companies provided smaller amounts. Various additional levels of corporate support were defined: platinum (donation of $\$ 100,000$ per year); diamond $(\$ 75,000)$; gold $(\$ 50,000)$; silver $(\$ 25,000)$; and bronze $(\$ 10,000)(24)$. The annual personal membership fee was set at $\$ 1000$, and the cost of a lifetime membership at $\$ 20,000$. Patrons of the Foundation would contribute $\$ 200$ annually (24).

Conflicts eventually arose between the CDDF and the CCFC because of perceived competition for financial and research support. In 1995, Dr Larry DaCosta, who was then Chair of the Medical Advisory Committee of the CCFC, recommended the appointment of Dr Thomson (to chair the Medical Advisory Committee) and Dr Ste-Marie (to chair the education committee). These physicians had made numerous contributions to the CCFC over the years, including chairing important committees. The Board of the CCFC rejected their appointments to the executive because they were also on the Board of the CDDF.

From its inception, the CDDF intended to obtain only starting funds from the pharmaceutical industry, and to approach the general public for further support. Nevertheless, because the CAG also receives industry funding and was concerned about a possible conflict of interest, it chose, at a single Board meeting, to dissociate itself from the CDDF (22). The CDDF Board thought that the decision would be quickly reversed and therefore restrained from any activity, including fundraising, that could be considered competitive by the CAG. They also invited Dr Gary Levy, president elect of the CAG, to join their Board, but the CAG Board refused to allow this to happen (25).

Dr Hunt joined the CDDF Board to facilitate the process of healing the rift between the CDDF and the CAG (26). Drs Beck and Thomson from the CDDF held fruitful discussions with Drs J Joseph Connon (Figure 4a) and Gary Levy (President and President Elect) of the CAG (27). A joint 


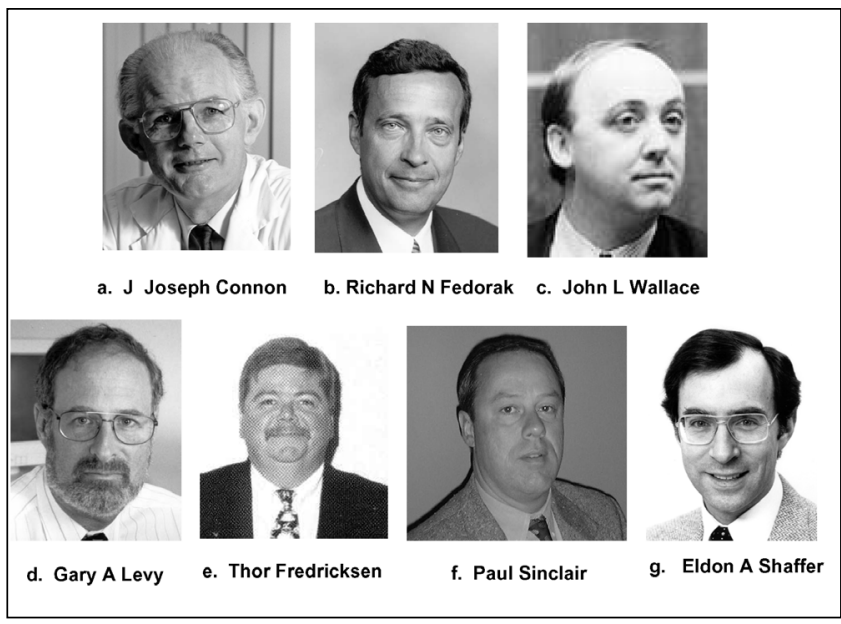

Figure 4) Individuals who helped to advance the Foundation from 1996. a Dr J Joseph Connon, Canadian Association of Gastroenterology (CAG) President 1996; b Dr Richard N Fedorak, CAG President 1998 to 1999; c Dr John L Wallace, CAG President 2000-2001; d Dr Gary A Levy, Canadian Digestive Disease Foundation President 1989 to present; e Mr Thor Fredriksen, Executive Director; f Mr Paul Sinclair, Executive Director; $\mathbf{g}$ Dr Eldon A Shaffer, second Chair of the Board, 1999 to present

committee was established in February 1997, comprised of Drs Hunt (Chair), Thomson and Ste-Marie from the CDDF and Dr Levy (Chair) from the CAG (28).

With the support of Dr Richard Fedorak (then President of the CAG) (Figure 4b), a meeting was held on March 25, 1998 between representatives of the CAG (Dr Gary Levy) and the CDDF (Mr Gerry Conroy and Dr Richard Hunt) (29). It was decided that there would be cross-representation on the two Boards and Research Committees. The CDDF would support patient education, while the CAG would advocate for the profession. The CAG Research Committee should concentrate on basic science, while the CDDF should focus on clinical research. The two organizations would share office space and coordinate their fundraising efforts. These principles were adopted in July 1998 (30). It was subsequently agreed that a single joint committee should deal with all research applications. Dr Levy (Figure 4d) joined the Board of the CDDF and was elected Acting President (replacing Dr SteMarie), Mr Conroy replaced Dr Thomson as Treasurer, and Dr Stephen Vanner replaced Dr Beck as the Chair of the Research Committee.

A combined Strategic Plan was developed by delegates from the CDDF (Mr Conroy and Drs Hunt and Levy) and the CAG (Mr Thor Fredriksen, Executive Director, and Dr Malcolm Champion, Chair of the Finance Committee), and was accepted by the CDDF Board on June 8, 1999 (31). Dr Eldon Shaffer (Figure 4e) was elected Chair of the Board of the CDDF and Dr Gary Levy became President. $\mathrm{Mr}$ Fredriksen became Executive Director. Gerry Conroy resigned as Treasurer, and financial matters were handled by Mr Graham and Mr Fredriksen until the appointment of Dr Champion in 2000. Mr Peter Dixon was invited to act as liaison to the pharmaceutical industry. The strategic plan stipulated that the Past President of the CAG would join the CDDF Board, and so Dr Fedorak became a Director.
AstraZeneca Canada enthusiastically provided funding for a CDDF office adjacent to that occupied by Pulsus Group Inc, the publisher of the Canadian Journal of Gastroenterology, and for the appointment of an Executive Director. Mr Paul Sinclair (Figure 4f), who was already Executive Director of the CAG, became the Executive Director of the CDDF and Ms Sandra Daniels was appointed as the office manager (32). Mr Thor Fredriksen was thanked for his many pro bono contributions as Executive Director, and plans were made to revise the bylaws of the Foundation (33). Ms Colleen L Albiston, Director of National Marketing for Ernst and Young, joined the Board to improve fundraising. Among other suggestions, she recommended creation of an interactive Web site, which was funded by AstraZeneca but entirely controlled by the Foundation.

On February 25, 2001 the CDDF and the CAG held a joint breakfast meeting at the Canadian Digestive Diseases Week, where Drs Levy and Hunt (from the CDDF) and Dr John Wallace (President of the CAG) (Figure 4c) announced to the membership of the CAG the full cooperation between the two organizations. The CDDF Board initiated a name change to the Canadian Digestive Health Foundation - Fondation canadienne pour la promotion de la santé digestive - which was approved by Industry Canada on December 15, 2001. A new logo was prepared. Figure 5 is a time sequence graph of the history of the Foundation.

\section{Research support}

\section{ACHIEVEMENTS}

In the early years of the Foundation, there was little money to distribute and one-year grants were provided to investigators with novel ideas in gastroenterology or nutrition. The first grants were for $\$ 20,000$ (in 1995) and $\$ 26,000$ (in 1996). Preference was given to researchers who had no other funds to initiate these studies. Dr Carlo Fallone (Figure 6) was the first to receive a grant from the Foundation (in 1995). Subsequent recipients are listed in Table 2 . The Foundation was gratified that all recipients were subsequently able to obtain ongoing support from other organizations. For example, Dr Fallone has since received the prestigious 'Research Scholar Award' and an operating grant of $\$ 120,000$ from the Fonds de la recherché en santé du Québec, as well as another grant for \$35,000 for research on Helicobacter pylori in hepatobiliary disease from the Canadian Helicobacter Study Group.

In 1995, Janssen Canada generously gave $\$ 150,000$ to the Foundation. Revenue Canada rules stipulated that charitable companies disburse $80 \%$ of their previous year's donations, (ie, $\$ 120,000$ ) but there were not enough applicants that met the criteria for new investigator grants. Moreover, because of the decision to cease fundraising activities until the disagreement with the CAG was resolved, the Foundation's funds were in danger of being depleted by 1997 . Therefore, on behalf of the CDDF, Ms Wenda Yenson (from Gowling, Strathy and Henderson) successfully applied for "Permission to Accumulate" funds for a 24-month period (34). As a result of hard work by Mr Gary Graham (Director), Mr Thor Fredriksen (Secretary and Executive Director), and Dr Gary Levy (President), the financial issues were resolved and operating grants could be provided until 1999. The temporary loss of income for the Foundation, however, resulted in there being insufficient funds to provide grants during the year 2000. 


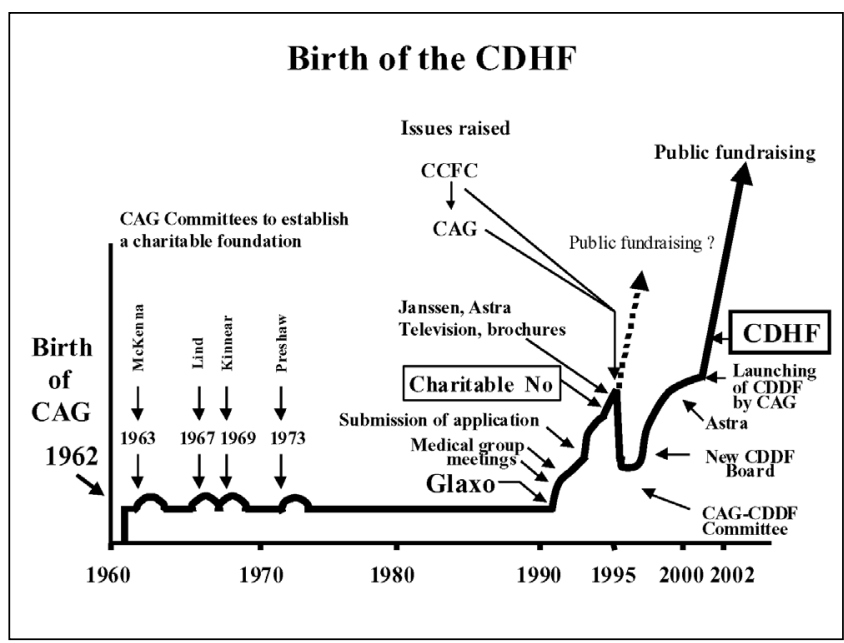

Figure 5) Time flow diagram of the Canadian Digestive Health Foundation (CDHF). One year after the birth of the Canadian Association of Gastroenterology (CAG) in 1963 Dr McKenna chaired a fundraising committee. This initiative and others by Drs James Lind, Douglas Kinnear and Roy Preshaw in 1967, 1969 and 1973, respectively, despite considerable effort, were unsuccessful. With the financial support of Glaxo Canada, a group of founding physicians decided to establish the Canadian Digestive Disease Foundation (CDDF). Preliminary meetings were held in January 1991 and January 1992. An application was made in April 1993 for a charitable number, and it was obtained for January 1995. Janssen was the second major donor in January 1995 and Astra provided brochures and television announcements for public fundraising. At the September 13, 1995 meeting of the CAG, the Canadian Crohn's and Colitis Foundation of Canada raised concerns about this new Foundation and the CAG Board reconsidered its previously strong support. Until relations between the CAG and CDDF were clarified, the CDDF desisted from further fundraising (see broken line arrow). In 1996, joint committees of the CAG and CDDF Board clarified the relationship between the CAG and the CDDF. On June 8th, 1999 a new CDDF Board was elected, with the past president of the CAG as a member. With the unrestricted financial support of AstraZeneca, funds were obtained for an office, educational material for fundraising and a Web site. In February 2001, at the Canadian Digestive Disease Week, the CAG and CDDF held a joint meeting to encourage financial support of the Foundation by CAG members and their patients. On December 2001, the Foundation name was changed to Canadian Digestive Health Foundation

Since 2001, funding to new investigators has been provided by the Foundation in conjunction with the CAG and/or the Canadian Institute of Health Research (CIHR, previously known as the Medical Research Council [MRC]), Abbott Pharmaceuticals, Byk Canada (now ALTANA Pharma Inc) and AstraZeneca.

Fellowship grants have been awarded to Drs Bruce Vallance (University of British Columbia), Nadia Pece-Barbara (University of Toronto), Johan Soderholm (McMaster University) and Jiaqing Huang (McMaster University). Research studentships have been provided, for completion of an $\mathrm{MSc}$ or PhD project, to seven individuals. Dr. Vanner has recently reviewed the Foundation's research achievements (35).

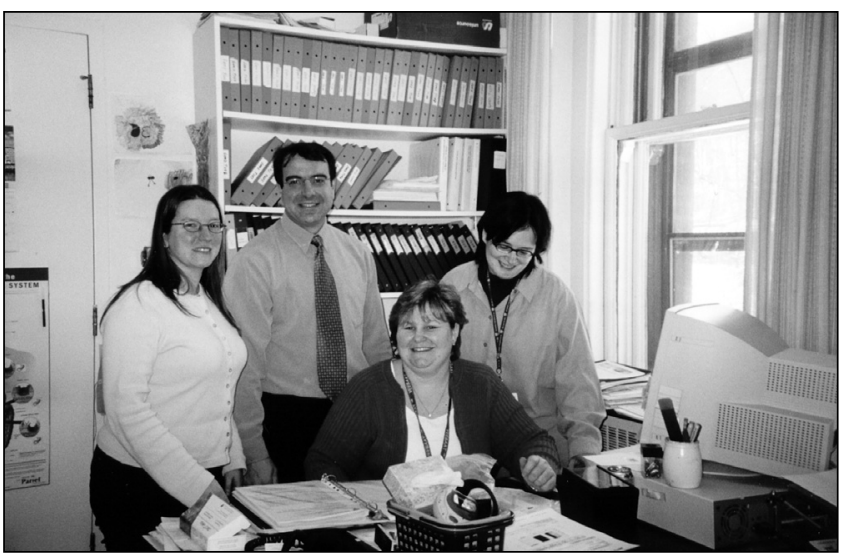

Figure 6) Outcome of the first one-year 'seeding grant' support. Dr Carlo Fallone in his laboratory seven years after receiving the Foundation's first grant

Education and public relations

Despite the relatively low public awareness of specific digestive diseases, these disorders are prevalent and result in significant work absences. Soon after obtaining a charitable number in 1995, the Foundation sought to determine the economic impact of functional dyspepsia and irritable bowel syndrome. A detailed review by one of the directors concluded that research support for digestive diseases is inappropriately low, considering the fact that they constitute the greatest direct economic burden of all disease groups in Canada (4). These data were presented at a symposium at the Canadian Digestive Disease Week 2002 (36), and were addressed by the Board (37). The Foundation is supporting Dr J Huang, who is publishing an analysis of the economic burden of digestive diseases (38).

The National office (especially Mr Paul Sinclair and Ms Sandra Daniels), with the support of an unrestricted grant from AstraZeneca, has produced a Web site (www.cdhf.ca) in English and French. The Web site describes the goals and brief history of the Foundation, its relationship with the CAG and the CIHR, and its research and educational achievements. It provides the names and photographs of current Board members, an introductory text for patients, and links to information about events and scientific meetings. The patient discussion forum includes a request for donations and is available only to registered members. In the "Ask a Specialist" feature, a gastroenterologist answers questions from the general public.

The education committee has created a new pamphlet for distribution to physicians, and brochures on dyspepsia and gastroesophageal reflux disease (Figure 7). In addition, a quarterly bilingual newsletter, Digestive Bites, has been prepared and distributed by AstraZeneca. As a holiday promotion to increase awareness of the CDHF in December 2002, AstraZeneca distributed to physicians 8000 packages of jelly beans attached to pamphlets on dyspepsia, on which were attached a sticker with the CDHF logo (in English and French) and the address of the CDHF Web site.

The Foundation has written articles for several magazines, including Reader's Digest, Glow, Fifty Plus and Geriatrics 8 
TABLE 2

Recipients of operating grants and new investigator awards

\begin{tabular}{|c|c|c|c|}
\hline Year & Researcher & Institution & Project \\
\hline 1995 & Carlo Fallone & McGill & Host and bacterial factors in the pathogenesis of Helicobacter pylori-associated disease \\
\hline 1996 & Johane P Allard & Toronto & Iron and vitamin E supplementation in rats with experimentally induced colitis \\
\hline 1997 & Claude Asselin & Sherbrooke & $\begin{array}{l}\text { Etude de l'expression de genes de la reponse inflammatoire lors de } \\
\text { l'inflammation intestinale }\end{array}$ \\
\hline 1997 & DSR Sarma & Toronto & Butyrylcarnitine and prevention of colorectal cancer \\
\hline 1998 & Brenda L Coomber & Guelph & Role of hypoxia in ulcerative colitis related colorectal cancer \\
\hline 1998 & Winnie WS Wong & Alberta & An in vivo study of the role of the HCV $3^{\prime}$ UTR core element in viral genome replication \\
\hline 1999 & Nicola Jones & Toronto & Pathogenesis and prevention of Helicobacter pylori infection \\
\hline 2001 & Anne Marie Salapatek & Toronto & Novel SNARE-K $\mathrm{K}^{+}$channel interactions modulate esophageal smooth muscle contractility \\
\hline 2001 & Nathalie Vergnolle & Calgary & Intestinal inflammation mediated by proteinase-activated receptors \\
\hline 2002 & Carole Creuzenet & Western Ontario & $\begin{array}{l}\text { Functional and clinical investigation of two new genes involved in the control of the } \\
\text { virulence of Helicobacter pylori }\end{array}$ \\
\hline 2002 & Joseph Romagnuolo & Calgary & Allopurinol for the prevention of ERCP-related pancreatitis \\
\hline
\end{tabular}

ERCP Endoscopic retrograde cholangiopancreatography; HCV Hepatitis C virus; UTR Untranslated region

Aging. Janssen-Ortho has organized six fundraising golf tournaments in British Columbia, Alberta, Ontario and Quebec.

\section{DISCUSSION}

The founding members of the CAG recognized the need for a fundraising organization to support research in gastroenterology $(5,6)$, but there have been many obstacles to overcome (3941). Unlike cardiac and neurological diseases (such as stroke), arthritis and cancer, digestive diseases do not elicit a strong emotional response among the general population.

Politicians and governmental agencies are susceptible to pressure from the general public and lay groups. For example, effective lobbying for human immunodeficiency virus caused research funding for infectious diseases in general to be $4.1 \%$ of the direct economic burden of infections, while research funding for digestive disease was only $0.5 \%$ of its direct economic cost (3). Moreover, breast cancer, which accounts for only $8 \%$ of all cancers, receives more research funding than do GI tumours, which represent $20 \%$ of cancers (4). Public reaction to the Krever report (42) has spurred the provision of $\$ 18$ million of government funds over five years for research on hepatitis C. This sudden increase in funding for hepatic research illustrates the importance of establishing organizations that support research in all aspects of digestive problems.

Despite the internationally acknowledged excellence of Canadian GI researchers, operating grants from the MRC for gastroenterology have steadily decreased (4). This might, in part, have been due to the lack of a specific grant committee for digestive diseases, in contrast to the presence of two full panels for heart disease. Funding for cardiology increased, while that for the three specialties represented by the Experimental Medicine Panel - digestive diseases, nephrology and hematology - decreased $(4,12,43,44)$. Despite criticisms and suggestions by the CAG to establish a separate Institute or for Digestive Disease and Nutrition Research $(45,46)$, this mixed committee structure has not been changed, even when the MRC was reorganized to form the CIHR.

Before the establishment of the CDDF, Canadian gastroenterologists helped the CAG to increase its research base, which reached over $\$ 1$ million by 1998 (47). Funding was stable for several years but rose to $\$ 1.5$ million in 2003 (48). It is unlikely that this figure will dramatically increase, because donations from the pharmaceutical industry are based on their monetary interest in promoting specific drugs, only certain amounts of money can be obtained without raising ethical concerns and the CAG cannot approach the general public for donations.

Canadian gastroenterologists have also supported established charitable organizations, while recognizing their limitations. For example, the Canadian Cystic Fibrosis Foundation, which was created in 1960, raised \$7 million in 2002/2003 (according to its Web site, www.cysticfibrosis.ca), but grant support for pancreatic disease during 1999/2000 was only $\$ 230,152$ (49) and, in 2002, only $\$ 41,000$ (50). The Canadian Celiac Association (www.celiac.ca) was founded in 1962 with financial assistance from the Kaufman Foundation, and provides only $\$ 5000$ for young investigators in celiac disease and dermatitis herpetiformis (51). The Canadian Liver Foundation has provided $\$ 6$ million for research in hepatology since it was created in 1969. Its support for research has been sporadic, however, in that new grants were suspended in 1998 and 1999, and resumed in 2000.

The Canadian Foundation for Ileitis and Colitis has been the most important charitable organization for GI research since it was established in 1974. Drs Richard Hamilton (Hospital for Sick Children, Toronto) and Kursheed Jeejeebhoy (Toronto General Hospital) played important roles in its early years, and it has also been strongly supported by key members of the CDDF. Based on funds provided in 1982 by the Kahanoff Foundation in Calgary, the Canadian Foundation for Ileitis and Colitis established intestinal disease research units at McMaster University (chaired by Dr Stephen Collins) and the University of Calgary (chaired by Dr Grant Gall). In 1992, its name was changed to the Crohn's and Colitis Foundation of Canada (CCFC), and it presently has over 50,000 supporters and 90 local volunteer groups. From 1976 to 2000, it provided several types of operating and student support grants, totaling $\$ 13,734,876$ (52).

It can be difficult for a charitable organization to deal with other groups with similar interests but different philosophies, financial structures and ethical concerns (53-55). Specifically, despite ongoing communication between the two Foundations (17), the CCFC in 1995 suddenly declared that the CDHF was in competition with it for funds and rejected the appointment 


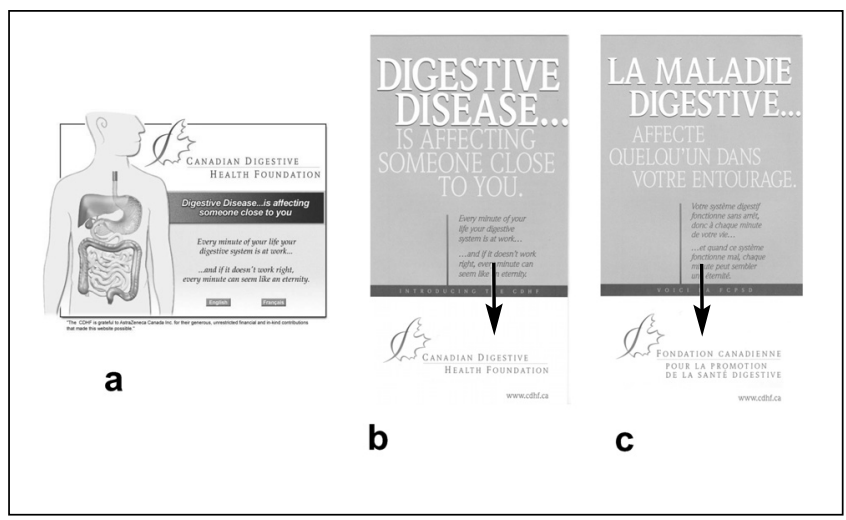

Figure 7) Web site and pamphlets of the Foundation. a Web site; $\mathbf{b}$ English pamphlet (Note the new logos marked by arrow); c French pamphlet (Note the new logos marked by arrow)

of two CDHF Board members to its medical advisory council. This was an unfortunate development, because the small size of the Canadian GI research community requires that resources be used synergistically. Furthermore, the two organizations have complementary roles. The CCFC is mandated to seek a cure for inflammatory bowel disease and would, therefore, tend to focus on experienced researchers with established laboratories and technical support. On the other hand, the CDHF specifically assists young investigators with novel ideas, who might otherwise abandon research careers due to inability to obtain funding. Some interaction at the executive level would help to coordinate efforts to support research in inflammatory bowel disease and other fields in gastroenterology and nutrition. The CDDF welcomed Mr Michael Howarth, the national Executive Director of the CCFC, to a Board meeting, but the invitation was declined (56). There remains today an ongoing effort by the CDHF to establish good relations with the CCFC.

The second ethical issue is the requirement for a charitable organization to not be unduly influenced by its donors (57). The CDDF's donors have mainly been pharmaceutical firms. The original donation by Glaxo Canada was as result of its chief executive officer's desire to develop Canadian gastroenterology (12), and donations continued even after the company could anticipate no further financial return. The second major donor was Janssen Canada, who wished to advance the objectives of the Foundation by advising the Board about fundraising issues and other matters. Even though Janssen hoped that brochures might be produced about GI motility (in keeping with their therapeutic focus), the dispute with the CAG caused a temporary cessation of direct contact with the pharmaceutical industry and these brochures were not actually produced.

The Foundation established a different type of mutually beneficial 'partnership' arrangement with Astra Canada in 1995 and with AstraZeneca Canada in 2001. The company distributed public education materials produced by the medical group of the Foundation. They included a film on the "Question on Indigestion" and brochures on indigestion, irritable bowel syndrome and ulcers. They have provided a focus for donations to the Foundation and promoted public understanding of gastroesophageal reflux disease and ulcer disease (areas of commercial interest to the company), without actually carrying any advertisement for the company. AstraZeneca also provides major funding for the basic needs of the Foundation.

The ethical issues involved in the relationship between charitable organizations and the pharmaceutical industry are enormous (58). The donations by Glaxo and Janssen to the CDDF were free of any restrictions and there was no actual partnership with these companies. The Foundation has been careful to ensure that corporate donors do not influence the allocation of research and educational funds. Materials that carry the Foundation logo reflect current medical knowledge and not a corporate bias. In particular, both the education committee and the entire Board determined that the dyspepsia brochure, although it is distributed by and carries the name of Astra as a supporter of the Foundation, did not constitute an advertisement for drugs produced by AstraZeneca.

The CDHF is justifiably proud of its achievements to date. With the full support of the Canadian gastroenterology community, the Foundation has a unique opportunity to fulfill its goal to rapidly decrease its financial dependence on the pharmaceutical industry and obtain the majority of its donations from the general public. It is hoped that, in the future, there will be cooperation among all groups that are interested in gastroenterology and nutrition. The Foundation is well positioned to serve its mandate to support research and education to improve the quality of life of Canadians with digestive diseases.

ACKNOWLEDGEMENTS AND POSSIBLE BIAS: The author of this manuscript was a member of the first CAG committee that attempted to establish a Foundation for digestive diseases. He was involved in the organization of both the CAG and the CDDF. Because a history written by a participant might be biased, specific statements have been supported by direct reference to minutes of meetings of these organizations and to letters kept in the archives. Furthermore, the original manuscript was reviewed by all participants to ensure its accuracy, and appropriate changes were made. The author is grateful to the present members of the Board, as well as to the President and Past President of the CAG, who carefully reviewed this manuscript. Dr Thomas Lay provided editorial support. This work was supported by a grant from the CAG on the History of the Canadian Association of Gastroenterology.

\section{APPENDIX A}

"At its most recent meeting, the Board of Directors of the Crohn's and Colitis Foundation of Canada approved a policy on InterFoundation Communication. It is our view that increasing demands and competition for scarce resources necessitates open dialogue and communication amongst and between Foundations with similar interests.

It is in this light that we have formulated our InterFoundation Communication Policy. As CDDF gets organized, if I, our Board of Directors, or our Executive Director can be of any assistance in helping to assure that there are no conflicts between our Foundations, please do not hesitate to contact us. Similarly, if there are areas of cooperation that would facilitate achievement of our mission, we would be only too happy to entertain proposals, particularly your goals regarding education and patient support, as well as your commitment to nutrition." 
APPENDIX B

TABLE 3

Participants in the meeting of January 18, 1992 with the Synapse Group, Toronto, Ontario

\begin{tabular}{ll}
\hline Dr I Beck & Dr M Ste-Marie \\
Dr L DaCosta & Dr A Thomson \\
Dr S Lemire & Mr P Agnes* \\
Dr G Levy & Mr G Conroy* \\
Dr E Shaffer & \\
\hline *Synapse Group &
\end{tabular}

\section{TABLE 4}

Physicians requesting incorporation of the Foundation Dr Ivan T. Beck

Dr Micheline Ste-Marie

Dr Alan BR Thomson

\section{APPENDIX C - continued \\ BOARD OF DiRECTORS OF THE FOUNDATION}

TABLE 8

1999 - 2001

\begin{tabular}{ll}
\hline Dr Eldon Shaffer (Calgary) & Chair, Board of Directors \\
Dr Gary Levy & President \\
Dr Micheline Ste-Marie & Past President \\
Dr Richard Hunt & Vice-President \\
Mr Gerry Conroy & Treasurer (temporary) \\
Dr Malcolm Champion & Treasurer \\
Mr Thor Fredriksen (Toronto) & $\begin{array}{l}\text { Secretary, Executive Director } \\
\text { (pro bono) }\end{array}$ \\
Dr Stephen Vanner & Chair, Research Committee \\
Dr Alan W Cockeram (Saint John) & Chair, Education Committee \\
Mr Peter Dixon (Toronto) & Liaison to Industry \\
Dr Ivan T Beck & Director \\
Dr Richard Fedorak & Director \\
Mr Gary Graham & Director \\
Dr Alan BR Thomson & Director
\end{tabular}

TABLE 9

2001

\begin{tabular}{ll}
\hline Dr Eldon Shaffer & Chair, Board of Directors \\
Dr Gary Levy & President \\
Dr Micheline Ste-Marie & Past President \\
Dr Richard Hunt & Vice-President \\
Dr Malcolm Champion & Treasurer \\
Mr Thor Fredriksen & Secretary \\
Dr Stephen Vanner & Chair, Research Committee \\
Dr Alan W Cockeram & Chair, Education Committee \\
Mr Peter Dixon & Liaison to Industry \\
Ms Colleen L Albiston (Toronto) & Chair, Fundraising \\
Dr Ivan T Beck & Director \\
Dr Richard Fedorak & Director \\
Mr Gary Graham & Director \\
Dr Alan BR Thomson & Director \\
Mr Paul Sinclair (Toronto) & Acting Executive Director \\
& (pro bono) \\
\hline
\end{tabular}

TABLE 5

1994 - 1996

\begin{tabular}{ll}
\hline Dr Ivan T Beck (Kingston) & $\begin{array}{l}\text { Chair, Board of Directors } \\
\text { Chair, Research Committee }\end{array}$ \\
Dr Micheline Ste-Marie (Halifax) & $\begin{array}{l}\text { President } \\
\text { Chair of Education Committee }\end{array}$ \\
Dr Alan BR Thomson (Edmonton) & $\begin{array}{l}\text { Secretary-Treasurer } \\
\text { Chair, Public Relations Committee }\end{array}$ \\
Mr Gerry Conroy (Hamilton) & Director \\
\hline
\end{tabular}

TABLE 6

$1996-1998$

\begin{tabular}{|c|c|}
\hline \multirow[t]{2}{*}{ Dr Ivan T Beck } & Chair, Board of Directors \\
\hline & Chair, Research Committee \\
\hline \multirow[t]{2}{*}{ Dr Micheline Ste-Marie } & President \\
\hline & Chair, Education Committee \\
\hline Dr Alan BR Thomson & Secretary-Treasurer \\
\hline Mr Gerry Conroy & Chair, Public Relations Committee \\
\hline Dr Richard Hunt (Hamilton) & Director \\
\hline Mr Gary Graham & Director \\
\hline
\end{tabular}

\section{TABLE 7}

1998 - 1999

\begin{tabular}{ll}
\hline Dr Ivan T Beck & Chair, Board of Directors \\
Dr Gary Levy (Toronto) & President \\
Dr Micheline Ste-Marie & Past president \\
Dr Alan BR Thomson & Secretary \\
Mr Gerry Conroy & Treasurer \\
Dr Richard Hunt & Director \\
Mr Gary Graham & Director \\
Dr Stephen Vanner (Kingston) & Chair of research committee \\
Dr Richard Fedorak (Edmonton) & Director \\
\hline
\end{tabular}

\section{APPENDIX C}

BOARD OF DiRECTORS OF THE FOUNDATION

\section{TABLE 10}

\section{2}

Dr Eldon Shaffer

Dr Gary Levy

Dr Micheline Ste-Marie

Dr Richard Hunt

Dr Malcolm Champion

Dr Stephen Vanner

Dr Alan W Cockeram

Dr Terry Ponich (London)

Mr Peter Dixon

Dr Ivan T Beck

Dr Alan BR Thomson

Ms Colleen L Albiston

Dr Johane Allard (Toronto)

Dr John Wallace (Calgary)

Mr Paul Sinclair

Chair, Board of Directors
President
Past President
Vice-President
Treasurer
Chair, Research Committee
Chair, Education Committee
Chair, Communications Committee
Liaison to Industry
Director
Director
Director
Director
Director
Acting Executive Director
$\quad$ (pro bono)




\section{REFERENCES}

1. Kohn R. The health of the Canadian people. A study of the Royal Commission on Health Services. Ottawa: Queen's Printer, 1967;283-97.

2. Fraser RD, Spasoff RA, Prime MG. Towards the establishment of health research priorities: An estimate of the economic burden of ill health. The Ontario Council of Health. Queen's Printer for Ontario, 1976

3. Moore, R, Mao Y, Zahng J, Clarke K. Economic burden of illness in Canada, 1993. Published by authority of the Minister of Health and Minister of Public Works and Government Services, Canada, 1993.

4. Beck IT. Disproportion of economic impact, research achievements and research support in digestive diseases in Canada. Clin Invest Med 2001;24:12-36.

5. Canadian Association of Gastroenterology. Minutes of the Board. January 17, 1963.

6. Canadian Association of Gastroenterology. Minutes of the Board. June 10, 1963.

7. Canadian Association of Gastroenterology. Minutes of the Board. June 26, 1964

8. Canadian Association of Gastroenterology. Minutes of the Board. January 19, 1967.

9. Canadian Association of Gastroenterology. Minutes of the Board. June 13, 1967

10. Canadian Association of Gastroenterology. Minutes of the Board. January 23, 1973.

11. Canadian Association of Gastroenterology. Minutes of the Board. May 21, 1973.

12. Beck IT, Depew WT. Canadian research Fellowship training programs in digestive sciences: achievements and challenges. Clin Invest Med 2001;24:44-53.

13. Canadian Digestive Disease Foundation. Pre-establishment minutes. January 18, 1991.

14. Canadian Digestive Disease Foundation. Pre-establishment minutes. January 18, 1992.

15. Canadian Association of Gastroenterology. Minutes of the Board. February 23, 1991.

16. Canadian Association of Gastroenterology. Minutes of the Board. February 1, 1992.

17. Hannah TE. Letter to Dr. Micheline Ste-Marie, re: Relations of CCFC and CDDF. 1995.

18. Canadian Digestive Disease Foundation. Minutes of the Board. April 14, 1994.

19. Canadian Digestive Disease Foundation. Minutes of the Board. January 19, 1995.

20. Canadian Digestive Disease Foundation. Minutes of the Board. September 13, 1995.

21. Canadian Association of Gastroenterology. Minutes of the Board. September 8, 1993.

22. Canadian Association of Gastroenterology. Minutes of the Board. September 13, 1995.

23. Canadian Digestive Disease Foundation. Minutes of the Board. October 4, 1995.

24. Canadian Digestive Disease Foundation. Minutes of the Board. September 17, 1994.

25. Levy GA. Letter to Dr. Alan Thomson, re: CAG executive decision. March 26, 1996.

26. Canadian Digestive Disease Foundation. Annual General Meeting. December 18, 1996.

27. Connon JJ. Letter to archivist of Canadian Association of Gastroenterology, re: Achievements as president. July 6, 1998.

28. Canadian Digestive Disease Foundation. Minutes of the Board. February 25, 1997.

29. Canadian Digestive Disease Foundation, Canadian Association of Gastroenterology. Minutes of a sub-committee of the Board. March 25, 1998
30. Canadian Digestive Disease Foundation. Minutes of the Board. July 3, 1998.

31. Canadian Digestive Disease Foundation. Minutes of the Board. June 8, 1999.

32. Canadian Digestive Disease Foundation. Annual General Meeting. June 29, 2000

33. Canadian Digestive Disease Foundation. Minutes of the Board. February 25, 2001.

34. Yenson W. Application for permission to accumulate funds. June 9, 1998.

35. Vanner S. The Canadian Digestive Health Foundation research program. Can J Gastroenterol 2002;16:645-6.

36. Champion M, Beck IT. Burden of gastrointestinal disease. Can J Gastroenterol 2002;16:A33. (Abst)

37. Canadian Digestive Disease Foundation. Minutes of the Board. November 17, 2000

38. Huang J, Irvin EJ, Hunt RH. Socioeconomic burden of digestive disorders in Canada: a retrospective and descriptive analysis. Can J Gastroenterol 2003. (In preparation)

39. Beck IT. Canadian gastroenterology: Yesterday, today and tomorrow. Clin Invest Med 1982;5:93-107.

40. Baird PA. Funding medical and health-related research in the public interest. Can Med Assoc J 1996;155:299-301.

41. Marshall E. Lobbyists seek to reslice NIH's pie. Science 1997;276:344-6.

42. Krever H. Commission of inquiry on the blood system in Canada: Final report. Canadian Government Publishing, Ottawa: 1997.

43. Bois P. Report of the President, Medical Research Council of Canada, 1988. Medical Research Council of Canada, Minister of Supply and Services, Canada, Ottawa: 1988.

44. Friesen HG. Report of the President, Medical Research Council of Canada, 1992. Medical Research Council of Canada, Minister of Supply and Services, Canada, Ottawa: 1992.

45. Beck IT. History of the first 30 years of the Canadian Association of Gastroenterology. Can J Gastroenterol 1992;6:345-64.

46. Fedorak RN. Canadian Institutes of Health Research: should there be an institute for digestive sciences? Can J Gastroenterol 1999; $13: 367-9$

47. Fedorak RN. Growth of the Canadian Association of Gastroenterology: controlled, effective and impressive. Can J Gastroenterol 1999;13:191-3.

48. Canadian Association of Gastroenterology. Minutes of the Board. February 21, 2003.

49. Yap R. Canadian Cystic Fibrosis Foundation. Letter, 1999. [provide more details, publication, letter to?]

50. Ethier K. Research support, Canadian Cystic Fibrosis Foundation. January 17, 2003. [more details needed, personal communication?]

51. Richards-Mason D. Canadian Celiac Association. Research grant support. Personal communication, 1999.

52. Howarth M. Crohn's and Colitis Foundation of Canada. Research program funding. 2000. (Brochure)

53. Voorneveld CR, Rubin LA. Unfair competition for charitable donations? CMAJ 1991;144:644.

54. Barnes NG, Fitzgibbons DA. Strategic marketing for charitable organizations. Health Mark Q 1992;9:103-14.

55. Anonymous. In: Virginia, Trigon and its opponents fight over how to split up the Blues' money. Trigon BlueCross BlueShield, Richmond, Virginia. Profiles Healthcare Mark 1996;12:15-20.

56. Howarth M. Letter to Dr Ivan Beck, re: attendance at CDDF Board meeting, May 27, 1996.

57. Billitery TJ. Technology and accountability will shape the future of philanthropy. The Chronicle of Philanthropy 2000;12:1-7.

58. Rakatansky H. Review article: gastroenterology and the pharmaceutical industry. Aliment Pharmacol Ther 2002;16:1859-66. 


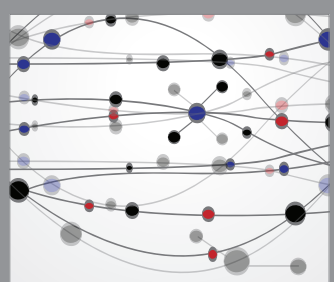

The Scientific World Journal
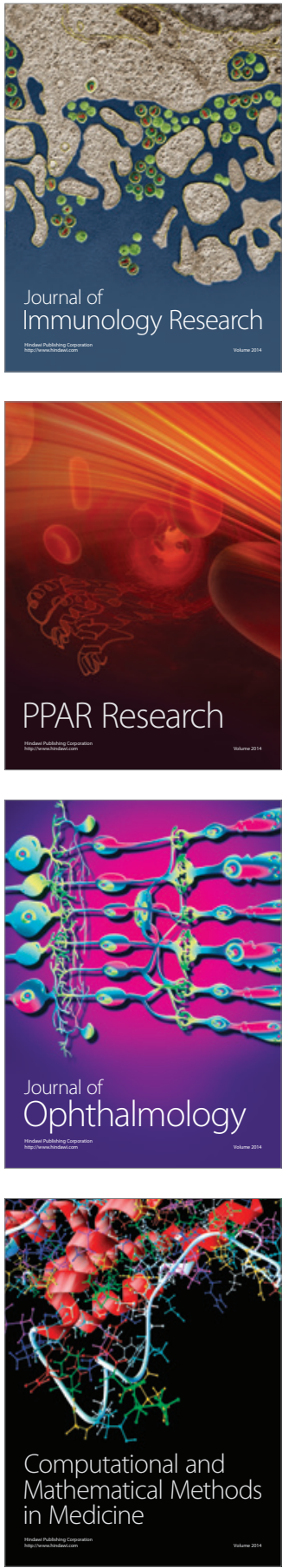

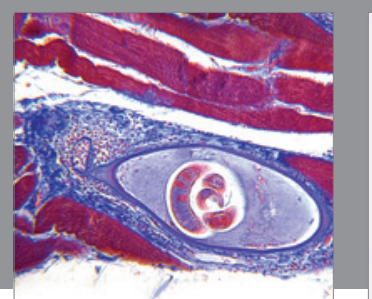

Gastroenterology Research and Practice

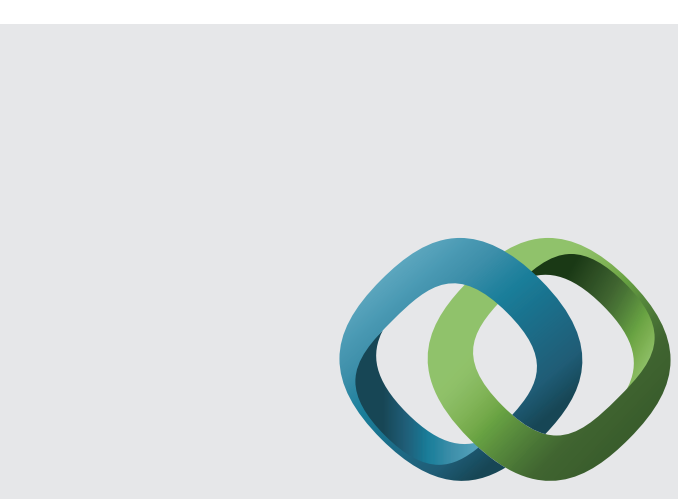

\section{Hindawi}

Submit your manuscripts at

http://www.hindawi.com
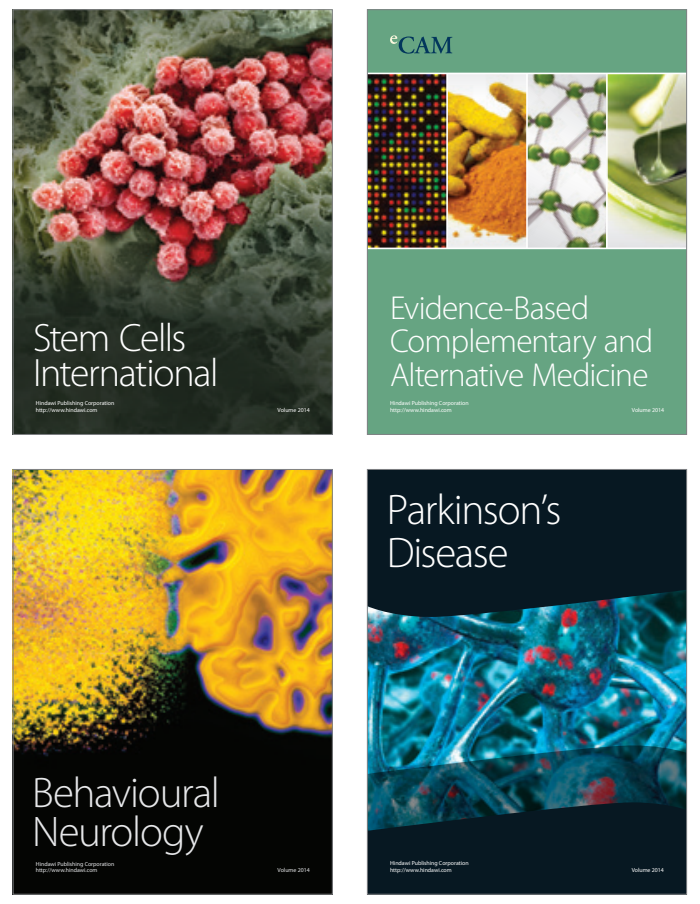
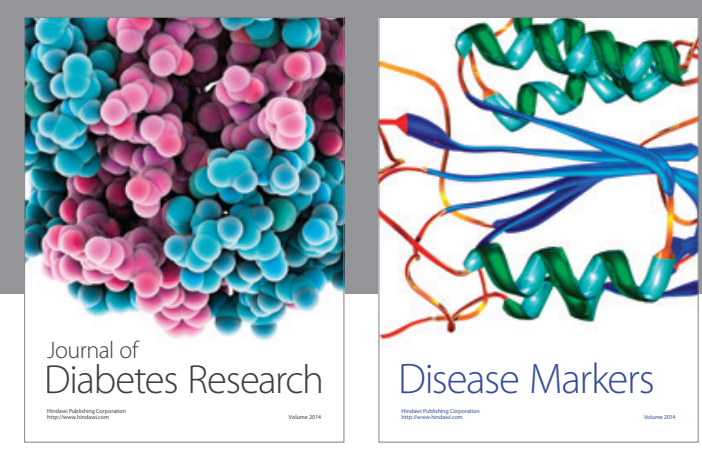

Disease Markers
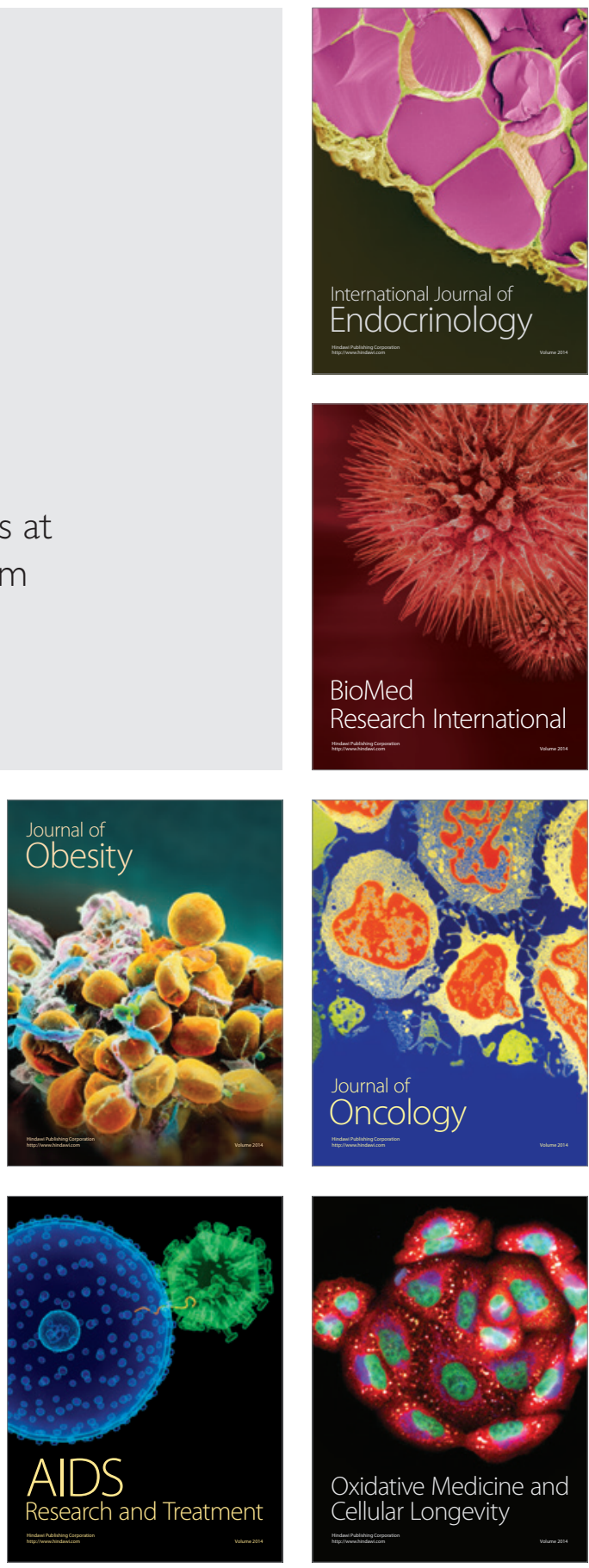